\title{
Host epithelial interactions with Helicobacter pylori: A role for disrupted gastric barrier function in the clinical outcome of infection?
}

\author{
Andre G Buret PhD, Jason P Fedwick PhD, Andrew N Flynn BSc
}

\begin{abstract}
AG Buret, JP Fedwick, AN Flynn. Host epithelial interactions with Helicobacter pylori: A role for disrupted gastric barrier function in the clinical outcome of infection? Can J Gastroenterol 2005;19(9):543-552.

Infection of the human stomach with Helicobacter pylori may develop into gastritis, ulceration, adenocarcinoma and mucosal lymphomas. The pathogenic mechanisms that determine the clinical outcome from this microbial-epithelial interaction remain poorly understood. An increasing number of reports suggests that disruptions of epithelial barrier function may contribute to pathology and postinfectious complications in a variety of gastrointestinal infections. The aim of this review is to critically discuss the implications of $H$ pylori persistence on gastric disease, with emphasis on the role of myosin light chain kinase, claudins and matrix metalloproteinases in gastric permeability defects, and their contribution to the development of cancer. These mechanisms and the associated signalling events may represent novel therapeutic targets to control disease processes induced by $H$ pylori, a microbial pathogen that colonizes the stomach of over $50 \%$ of the human population.
\end{abstract}

Key Words: Epithelial; Gastric cancer; Gastritis; Helicobacter; Permeability; Tight junctions
Les interactions épithéliales de l'hôte avec l'Helicobacter pylori : Un rôle pour le dérèglement de la fonction de la barrière gastrique dans l'issue clinique de l'infection ?

\begin{abstract}
L'infection de l'estomac humain à l'Helicobacter pylori peut se transformer en gastrite, en ulcération, en adénocarcinome et en lymphomes muqueux. Les mécanismes pathogènes qui déterminent l'issue clinique de cette interaction épithéliale microbienne demeurent mal compris. Un nombre croissant de comptes rendus laissent supposer que des dérèglements de la fonction de la barrière épithéliale contribueraient à la pathologie et aux complications postinfectieuses de diverses infections gastro-intestinales. La présente analyse vise à exposer d'un point de vue critique les répercussions de la persistance du $\mathrm{H}$ pylori sur la maladie gastrique, en s'attardant sur le rôle de la myosine kinase, des claudines et des métalloprotéinases matricielles dans les anomalies de la perméabilité gastrique, et leur con tribution à l'apparition du cancer. Ces mécanismes et les événements de signalisation connexes peuvent représenter de nouvelles cibles thérapeutiques pour contrôler les processus de la maladie induits par le $\mathrm{H}$ pylori, un pathogène microbien qui colonise l'estomac de plus de 50 \% de la population humaine.
\end{abstract}

Uelicobacter pylori persistently colonizes the stomach of over Hone-half of the human population and, in the majority of cases, causes chronic gastritis. However, the microbial epithelial interactions and gastritis associated with infection may also cause gastroduodenal ulcers, gastric adenocarcinoma and mucosal lymphomas (1-3). An American study (4) found that the lifetime risk for development of gastric cancer in those infected with $\mathrm{H}$ pylori ranges between $1 \%$ and $3 \%$. Despite intensive study, the host-microbial interactions that determine the clinical outcome of infection remain unknown. The main $H$ pylori virulence factors that have been associated with pathogenesis to date include the pathogenicity island-encoded protein cytotoxin-associated antigen (CagA) and the vacuolating $(\mathrm{Vac} A)$ cytotoxin $(2,3,5-7)$. Indeed, $\mathrm{Cag} A$ is the factor that has most often been linked with the development of adenocarcinoma $(2,3,7)$. H pylori CagA and VacA have been shown to disrupt epithelial barrier function, and the focus of the present review is to discuss how this phenomenon may participate in disease pathogenesis. Insights into the operating principles that regulate the interactions between $\mathrm{H}$ pylori and host epithelia may improve our understanding of the initiation of the diverse disease processes associated with the infection, and help identify new therapeutic targets. The present review critically discusses the current knowledge of the effect of
$H$ pylori on epithelial permeability and explores its possible clinical significance, with particular emphasis on how it may be linked to the development of gastric cancer.

\section{H PYLORI PERSISTENCE AND DISEASE}

$H$ pylori infection of the human stomach is most commonly acquired in childhood. Although this microaerophilic bacterium remains in the gastric environment of its host for decades, consequences of colonization are usually benign, marked by a persistent mucosal inflammatory reaction $(7,8)$. However, in a subset of hosts, this gastritis may lead to severe pathology. In addition to its well-established role in peptic ulcer disease and noncardiac gastric adenocarcinoma, $\mathrm{H}$ pylori infection has also been implicated in the development of extragastroenteric diseases (1-3,7,9-13). The possible implication of altered epithelial permeability in the etiology of any of these abnormalities remains a topic of ardent controversy.

The ability of $H$ pylori to chronically colonize the human stomach and to cause disease is the focus of intense research and is the topic of recent reviews (5-8). The scope of host-microbial interactions and their influence on disease development are briefly reviewed in the following section. The difficulty of infecting animal models with human $H$ pylori isolates should be noted. Similarly, nontransformed confluent human gastric 
cell lines with functional tight junctions have only been established very recently (14). This has made research difficult, and forced scientists to use models of epithelial cells belonging to phenotypes that may normally not be infected by $\mathrm{H}$ pylori. In view of these limitations, while highlighting observations based on human gastric cells, the present review critically addresses research findings that are most relevant to the topic, regardless of the model system being used.

$H$ pylori is well-adapted to the hostile environment of the human stomach. The bacterium is likely transmitted via the fecal-oral route and, once established, can persist for the lifetime of the host. H pylori demonstrates a marked tropism for gastric mucus-producing epithelial cells (15). The bacterium expresses a number of adhesins that allow tight attachment to epithelial cells; this interaction is ultimately the cause of the chronic inflammatory response in the host $(5,7,16-18)$. These adhesins also direct $H$ pylori colonization to areas of the stomach containing only few parietal cells, further allowing the bacterium to circumvent gastroprotective acid production (19). Facilitation of this process appears to be aided by the fact that longstanding $\mathrm{H}$ pylori-induced gastritis leads to the loss of specific cell types in the stomach, and a shift in the types of glycans expressed on the surface of gastric epithelial cells $(16,19)$. Remarkably, therefore, $H$ pylori can modulate its adhesin expression pattern to colonize a variety of gastric niches, and to selectively avoid areas of active inflammation that may be capable of clearing the infection. H pylori is an incredibly adaptable micro-organism that is able to persist in the changing and hostile environment of the stomach, even in the presence of a chronic inflammatory response.

\section{IMMUNOPATHOLOGY OF H PYLORI INFECTIONS}

There is growing evidence that, in addition to being unable to clear the infection, the $\mathrm{T}$ helper cell $(\mathrm{Th})-1$ polarity of the host response to $H$ pylori infection contributes to the development of disease in the host. Production of Th-1 cytokines, including interferon gamma (IFN $\gamma$ ), tumour necrosis factor alpha $(\mathrm{TNF} \alpha)$ and interleukin-1beta (IL-1 $\beta)$ are increased during $H$ pylori infection, which in turn amplifies the inflammatory response (20). IL-1 $\beta$ is also a potent inhibitor of gastric acid secretion (21). Interestingly, polymorphisms in the human IL-1 loci, which are implicated in the increased IL-1 $\beta$ production, are also associated with hypochlorhydria and gastric cancer in patients infected with $H$ pylori $(22)$. Several reports $(23-26)$ have suggested that the host $\mathrm{Th}-1$ response to the infection may contribute to the carcinogenic effects of the bacterium. Similarly, $H$ pylori-stimulated upregulation of inducible nitric oxide synthase promotes apoptosis and induces carcinogenesis during the infection, via mechanisms that remain unclear (27-30). In addition, though still incompletely understood, the events leading to $\mathrm{H}$ pylori-induced B cell proliferation and mucosa-associated lymphoid tissue lymphoma appear to involve cytokines of both the Th-1 and the Th-2 subsets (31-33).

The principles governing the host microbial interactions during an infection with $H$ pylori result from a complex multifactorial process. For example, microbial factors may include adaptive point mutations that allow variants to emerge after selective pressure (eg, antibiotic therapy) (34), restriction barriers to genetic transformation that favour maintenance of diversity (35), and other factors that add to genetic diversity, such as local selection due to ligand specificity for local receptors $(16,36)$. Conversely, host factors that contribute to the chronicity of infection include determinants of bacterial tropism to various gastric niches that circumvent gastroprotective barriers like acid-producing parietal cells (19), and factors that polarize the primary adaptive immunity to $H$ pylori to a Th-1 response (20).

Th-1 immunity also appears to compromise parietal cell responses and induce proliferation of epithelial glycan receptors for $H$ pylori adhesins (37). Interestingly, concurrent intestinal helminth infections that drive a polarized Th-2 immune response reduce $H$ pylori-induced gastritis and premalignant gastric atrophy (38). This phenomenon has been linked to the 'African enigma', which refers to the surprisingly low rates of gastric cancers in African countries despite equally high prevalence rates of $H$ pylori infection (38). Low-grade mucosa-associated lymphoid tissue lymphomas often regress on elimination of $\mathrm{H}$ pylori and, conversely, they may relapse after $H$ pylori reinfection (39-41). Persistent host-microbe interactions with $\mathrm{H}$ pylori also increase the risk for gastric adenocarcinoma in humans, the second leading cause of cancerrelated death worldwide $(8,10,42)$. As a result, $H$ pylori is now considered to be a class 1 carcinogen, and this risk is most commonly associated with the ability of some strains to inject CagA into the host cell $(43,44)$. The development of H pyloriinduced 'intestinal type' adenocarcinoma occurs in a welldefined sequence of events. First, the normal gastric mucosa progresses through chronic superficial gastritis, which then leads to atrophic gastritis, and the still poorly understood formation of gastric ulcers. Atrophic gastritis can progress into metaplasia, dysplasia and, ultimately, adenocarcinoma $(3,8,10,42,45)$. Yet, for reasons that remain unclear, only a relatively small number of $H$ pylori-infected patients ever proceeds from gastritis to neoplasia formation (4). Together, these observations are consistent with the hypothesis that the oncogenic potential of $\mathrm{H}$ pylori may be strain- and/or host-dependent, and related to specific signalling events of the epithelialmicrobial interaction. Little is known about how these events may be causally related, and the role played by determinants of epithelial barrier function in carcinogenesis remains obscure. As discussed below, such determinants of epithelial barrier may include tight junctional proteins including claudins. Figure 1 illustrates the main components of gastric tight junctional and adherens proteins discussed in the present review.

\section{Loss of epithelial barrier function: The role of claudins and matrix metalloproteinases}

While the majority of $H$ pylori micro-organisms swim in the mucus layer coating the gastric epithelium, approximately $10 \%$ eventually adhere to the epithelial cells (46). H pylori attachment to epithelial cells alters the outcome of infection. Using a murine model of infection, a recent study (47) observed that in the gastric mucosa, the mucus cell exhibits the greatest transcriptional response to $H$ pylori. Subsequent cellular alterations implicate genes that broadly regulate inflammation, angiogenesis, iron metabolism and tumour suppression (47). Loss of cell-to-cell adhesion is a well-established precursor of gastric adenocarcinomas, and abnormalities of the adherens junctional protein E-cadherin have been found to contribute to this phenomenon as well as to the migratory potential of tumour cells $(48,49)$. In keeping with these findings, functional inhibition of E-cadherin through mutations initiates 


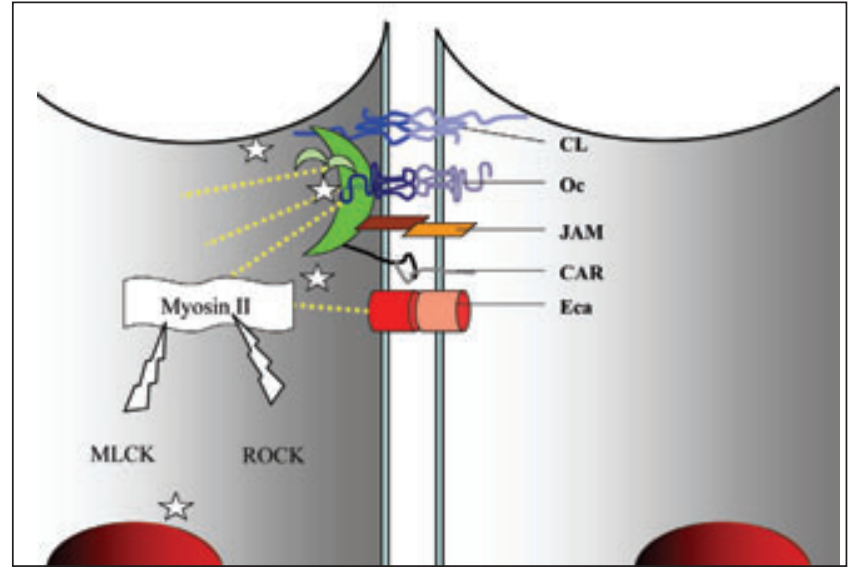

Figure 1) Schematic illustration of the junctional complexes linking polarized epithelial cells. Comprehensive listings of tight junctional elements are available in a number of reviews (68-75). The various components of the intercellular junctions have been assigned to three different groups, and their main representatives are listed below, giving particular emphasis to those discussed in the text. 1) Intercellular junctional proteins: these include tight junctional proteins per se such as claudins (CL), occludin (Oc), junctional adhesion molecules (JAM), and coxsackie virus and adenovirus receptor (CAR), as well as proteins of the adherens junctions such as E-cadherin (Eca) which helps initiate tight junctional assembly. Any of these may be directly modified by microbial products to increase paracellular permeability. 2) Junctional plaque proteins (crescent-shaped in the figure): these include scaffolding protein interaction domain proteins such as those belonging to the zonula occludens family, cingulin or those representing partitioning-defective proteins (PAR3 and PAR6). The main function of these proteins is to help crosslink tight junctional proteins to the actin cytoskeleton (dotted lines). 3) Regulatory factors (star-shaped in the figure): these products may be cytosolic or linked to tight junctional proteins, to the plasma membrane, to cellular actin filaments or to the nucleus. They include atypical protein kinase C, zonula occludens-1-associated nucleic acid binding protein and a number of $\mathrm{G}$ proteins, as well as a long list of other factors. Their principal function is to signal and regulate, at the transcriptional or post-transcriptional levels, the assembly and/or function of tight junctions. The myosin II-actin complex may be modulated by myosin-light chain kinase (MLCK) or Rho kinases (ROCK), which allows the opening of tight junctions and increases paracellular permeability

gastric tumourigenesis (50). A recent study (51) has now established a possible link between $H$ pylori and these processes. Indeed, it was found that $H$ pylori modulates the migration of human gastric epithelial cells by destabilizing E-cadherin in a Rho-GTP-dependent fashion. Consistent with these observations, $\mathrm{H}$ pylori is capable of altering epithelial permeability, a topic that will be discussed in the following paragraphs. Among the various tight junctional proteins that are affected by $H$ pylori, the authors recently observed that the bacterium was capable of disrupting tight junctional claudin-4 and -5 in a strain-dependent manner (52) (Figure 2). In addition to cell adhesion, polarity may also be lost during carcinogenesis, and a role for disruption of specific claudins in these events has been recently suggested. Indeed, while its role in epithelial barrier is well-established, claudin-4 expression is also inversely correlated with the metastatic potential of pancreatic cancer cells $(53,54)$. Intriguingly in the context of the present article, a recent report (55) indicates that loss of tight junctional claudin-4 correlates with poor differentiation in advanced gastric adenocarcinomas. This observation offers further support
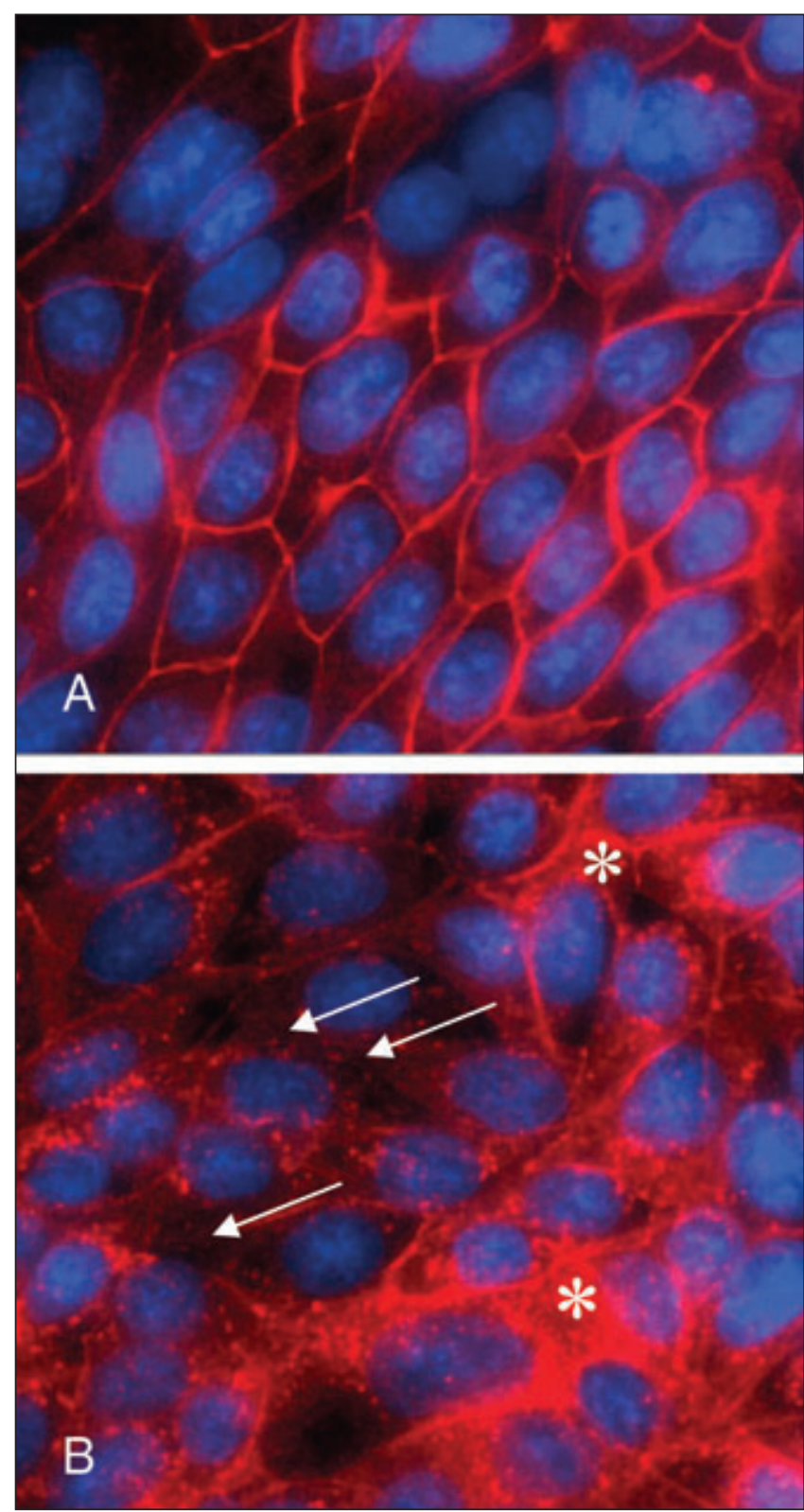

Figure 2) Helicobacter pylori disrupts tight junctional claudin-4. Shown are representative micrographs illustrating claudin-4 (red) and cell nuclei (blue) in epithelial monolayers after $6 \mathrm{~h}$ incubation with $\mathrm{H}$ pylori SS1, a human clinical isolate passaged through mice. * Abnormalities include focal disruptions of claudin-4 along the pericellular junctions (arrows) and punctate redistribution of claudin-4 into cytosolic compartments. Original magnification $\times 400$

to the hypothesis that disruption in gastric epithelial barrier function may influence the clinical outcome of infection. Similarly, loss of claudin-7 has recently been implicated in the ability of breast cancer cells to disseminate (56). Therefore, the tight junction acts as a scaffold for signalling proteins involved in cell growth and differentiation, and loss of normal tight junctional structure and function, possibly via disruptions of claudins, may represent an important precursor to the development of human carcinomas (57).

Matrix metalloproteinases (MMP), a family of enzymes associated with inflammatory processes and capable of degrading 
components of the extracellular matrix, have become intriguing candidates on the list of potential markers of oncogenesis. For example, MMP-7, also called matrilysin, is found in high concentrations within premalignant gastric ulcers as well as in pancreatic intraepithelial neoplasia (58-60) implying that, in addition to its role in host defense and tissue remodelling, this enzyme may also be an early marker of carcinogenesis. Clearly, additional research is needed to establish a cause-to-effect relationship in this interaction. While MMP-7 expression is known to increase in response to $H$ pylori infection $(60)$, a potential relationship with defects in epithelial barrier structure and function has yet to be established. Studies are needed to assess whether and how elevated MMP-7 and altered claudin-4 (and possibly claudin-7) may coincide with events leading to increased gastric permeability, which may then help link the loss of epithelial barrier with lesions of premalignant significance.

In addition to their effects on epithelial barrier function, the upregulation of host proteinases may also contribute to the mitogenic response of epithelial cells. A number of growth factors and their receptors are upregulated in response to $H$ pylori exposure. Specifically, epidermal growth factor (EGF) receptor expression is increased during $H$ pylori-induced gastritis in humans and this micro-organism can activate the EGF receptor on gastric epithelial cells $(61,62)$. H pylori infection also leads to an increase in the EGF receptor ligand, heparin-binding EGF (HB-EGF) (62,63). Current research data (64) suggest that $H$ pylori activates a G-protein coupled receptor, leading to MMP release and cleavage of HB-EGF. The proteinases responsible for the cleavage of $\mathrm{HB}-\mathrm{EGF}$ remain unknown. In addition to stimulating MMP-7, H pylori increases MMP-1 and MMP-3 release and activity in transformed adenocarcinoma gastric stomach epithelial cancer cell lines and the microorganism may itself have MMP-3 activity (65). Cag-positive strains activate nuclear factor-kappa $\mathrm{B}$ and induce the expression of MMP-9 in MKN28 and MKN45 gastric epithelial cells, and increased levels of MMP-9 are found in biopsies from $H$ pylori-infected patients (66). Overall, altered expression of host growth factors in response to $H$ pylori signalling has been implicated in gastric adenocarcinomas, and MMPs may play an important role in this processs. It has been recently demonstrated that the $H$ pylori-induced EGF receptor transactivation required metalloproteinase cleavage of HB-EGF (63). However, the exact molecular, biochemical and physiological mechanisms involved in this chain of events remain unclear.

\section{Loss of epithelial barrier function: The role of myosin light chain kinase}

The gastric epithelium acts as a selective barrier that prevents potentially harmful luminal agents (eg, microbial products, food antigens, toxins) from penetrating underlying tissues, while allowing for exchanges of ions and small molecules (67). Tight junctions and adherens junctions between gastric epithelial cells play a key role in this barrier function, and consist of a complex interaction among several protein families. Tight junctions can easily be recognized under transmission electron microscopy $(68,69)$. Figure 1 offers an overview of the main tight junctional structures discussed in the present review. For comprehensive articles on the composition and function of these structures, interested readers are directed to recent reviews on this topic (68-75). Tight junctions comprise:

- transmembrane proteins belonging to several families including occludin, claudins and the immunoglobulin superfamily members: junctional adhesion molecules (JAM) and coxsackie virus and adenovirus receptor;

- an ever-increasing number of cytosolic proteins, including zonula-occludens ( $\mathrm{ZO})-1,-2$ and -3 , and partitioning defective proteins (eg, PAR3 and PAR6), that form complex junctional plaques; and

- a mixed group of cytosolic, membrane-bound or nuclear-associated proteins that interact with the former two groups to regulate epithelial permeability, polarity and proliferation.

Transmembrane proteins are thought to directly regulate paracellular diffusion. Proteins of the tight junctional plaques may act as adaptors (eg, $\mathrm{ZO}$ proteins), and the cytosolic and nuclear components function as signalling and regulatory proteins. Adaptor proteins help connect the transmembrane components to cytosolic factors such as GTPases and protein kinases. Many tight junctional proteins are directly or indirectly attached to actin filaments. For example, claudins, occludin and junctional adhesion molecules are anchored to actin filaments and myosin light chain (MLC) of the perijunctional actinomyosin ring by the linker proteins of the $\mathrm{ZO}$ family (76-78). Paracellular permeability may be increased by phosphorylation or degradation of transmembrane tight junctional proteins (79). In addition, dephosphorylation of MLC by MLC kinase (MLCK) or by Rho kinases may also physiologically regulate paracellular permeability by placing tension on the tight junctional complexes (80). The molecular mechanisms responsible for this process are topics of intensive research efforts.

It has been well-established that the paracellular permeability offered by tight junctions could be altered in response to physiological and pathological stimuli (81). Recent reports $(80,82,83)$ indicate that a variety of pathogens may actively disrupt epithelial barrier function by subverting cellular pathways, including those that lead to the activation of MLCK. As illustrated in Table 1 , these effects are commonly mediated via microbial toxins and/or proteases. Interestingly, a recent study $(84,85)$ has found that a membrane permeant inhibitor of MLCK was able to inhibit the tight junctional disruptions induced by enteropathogenic Escherichia coli (EPEC) or TNFa and IFN $\gamma(84,85)$. In view of the implication of TNF $\alpha$, a Th-1 cytokine, in the modulation of barrier function, and the significance of Th-1-mediated pathogenesis during $\mathrm{H}$ pylori infections, these findings may provide fertile ground from which to develop a new class of therapeutic agents targeting the loss of gastrointestinal barrier function.

$H$ pylori preferentially adheres near the tight junctions of gastric mucous cells $(15,47,87)$. Strains possessing the Cag pathogenicity island translocate the CagA protein into host cells via a type IV secretory system $(88,89)$. Findings from recent studies (90) using Madin-Darby canine kidney cells or gastric adenocarcinoma cells indicate that translocated CagA increases paracellular permeability by recruiting ZO-1 and JAM to sites of bacterial attachment. Other reports (91) have shown that $\mathrm{H}$ pylori strains producing VacA modulate the integrity of the epithelium by increasing tight junction permeability to small ions and molecules. Indeed, adherence of VacA-producing strains reduced transepithelial electrical resistance in cell monolayers in vitro, while isogenic VacA -/- mutants lost this ability. Acid-activated VacA on its own was also found to increase paracellular permeability for small molecules in vitro, 
TABLE 1

Examples of pathogen-epithelial interactions known to modulate epithelial permeability

\begin{tabular}{|c|c|c|c|}
\hline Organism & Virulence factor & Mechanism & Reference \\
\hline \multicolumn{4}{|l|}{ Viral } \\
\hline Reovirus & & Binds JAM, effect on permeability unknown & 124 \\
\hline Rotavirus & & Metabolic interference & 103 \\
\hline Adenovirus & Fibre protein & Binds coxsackie adenovirus receptor & 122 \\
\hline \multicolumn{4}{|l|}{ Bacterial } \\
\hline Vibrio cholerae & ZOT & PKC activation & $102,148,149$ \\
\hline \multirow{2}{*}{ Enteropathogenic E coli } & & MLCK activation & 83 \\
\hline & EspF/T3SS & Unclear & 151 \\
\hline Enterohemorrhagic $E$ coli & T3SS & E-cadherin disruption, rac-1 and ezrin activation & $79,150,152$ \\
\hline Bacteroides fragilis & Fragilysin & E-cadherin disruption & 153 \\
\hline Clostridium difficile & Toxin A/B & Rho-GTPase and PKC activation & 154 \\
\hline \multicolumn{4}{|l|}{ Parasitic } \\
\hline Giardia species & Unclear & Caspase-3-dependent ZO-1 disruption, MLCK & 82,109 \\
\hline \multicolumn{4}{|l|}{ Other } \\
\hline Aspergillus, Penicillium & Ochratoxin A & Disruption of claudin-3 and -4 & 158 \\
\hline
\end{tabular}

CagA Cytotoxin-associated antigen; Grb2 Growth factor receptor bound protein 2; GTPase Guanosine triphosphatase; JAM Junctional adhesion molecules; MLCK Myosin light chain kinase; PKC Protein kinase C; SHP-2 Src homology 2 domain-containing protein-tyrosine phosphatase; T3SS Type 3 secretion system; T4SS Type 4 secretion system; TJ Tight junction; VacA Vacuolating cytotoxin A; ZO-1 Zonula occludens; ZOT Zonula occludens toxin

without affecting the transcellular fluxes of $5 \mathrm{kDa}$ or $47 \mathrm{kDa}$ probes (92). In addition to a direct effect of the bacterium, transmigration of inflammatory cells in response to infection may also contribute to a disruption of epithelial barrier function (93). The degree of $\mathrm{H}$ pylori-induced gastritis has been associated with permeability changes (94), consistent with the findings that TNF $\alpha$ and IFN $\gamma$ are able to disrupt epithelial junctions by activating MLCK $(85,86)$. However, studies $(95,96)$ involving human subjects have argued for and against the ability of the bacterium to disrupt tight junctions of the gastric epithelium. Yet, $\mathrm{H}$ pylori has the ability to increase the passage of food antigens across human gastric biopsies (97), as well as in animal model systems (98). These findings are consistent with the observations that the infection may be associated with the development of food allergy $(99,100)$. Intestinal pathogens such as Vibrio cholerae, Salmonella species, E coli, Rotavirus, Shigella species and Giardia species all have been found to directly alter tight junction permeability, a change suggested to contribute to disease symptoms $(82,83,101-104)$. Therefore, whether and how $H$ pylori-induced epithelial permeability defects may influence the clinical outcome of this infection represents an important topic for future research.

Loss of epithelial barrier function: Signalling events Molecular signalling of epithelial permeability is a fast-growing field of investigation. Studies (105) have found that integrinmediated cell migration was mediated by MLCK, following a cascade of events in which Ras, extracellular signal-regulated kinase (ERK), and mitogen-activated protein kinase (MAPK)/ERK serve as essential downstream effectors. However, signalling events implicated in the MLC-dependent regulation of epithelial tight junction and barrier function, particularly in the gastric mucosa, are less clear. A variety of cellular events are associated with the epithelial abnormalities caused by $\mathrm{H}$ pylori, including apoptosis, cytoskeletal and tight junctional alterations, and loss of barrier function. The complex signalling events that may be responsible for $\mathrm{H}$ pylori-induced disruptions of gastric epithelial barrier function remain unclear. Figure 3 illustrates possible mechanisms suggested by the scientific literature currently available. $H$ pylori has proapoptotic effects (106-108), and immune or microbially induced enterocyte apoptosis may directly increase epithelial permeability (109111). Any of these alterations can be linked to MLCK, which further underscores the gatekeeper role played by phosphorylated MLC in gastrointestinal barrier function. Moreover, activation of PAR1, which results in caspase-3-dependent loss of barrier function (112), microbially induced loss of epithelial barrier (Table 1) and EGF signalling (113), may each implicate phosphorylation of MLC in their epithelial signalling cascade. Downstream from Rho, Rho-associated kinase (ROCK) serine/threonine kinase isoenzymes are known to modulate cytoskeletal arrangements and cellular contractility via MLC, as well as tight junctional function (114-116). Furthermore, intracellular caspases can cleave ROCK and its constitutively active cleavage products lead to the activation of MLC, and ultimately to the formation of apoptotic membrane blebbing and the chromatin condensation characteristic of programmed cell death (116-119). Interestingly, MAPK activation is also implicated in tumour progression (120). While levels of Rho-GTP are increased during the $H$ pylori-induced translocation of E-cadherin from membrane to cytosolic vesicles (51), the implication of ROCK in H pylori-induced epithelial cell signalling and subsequent injury is less clear. 


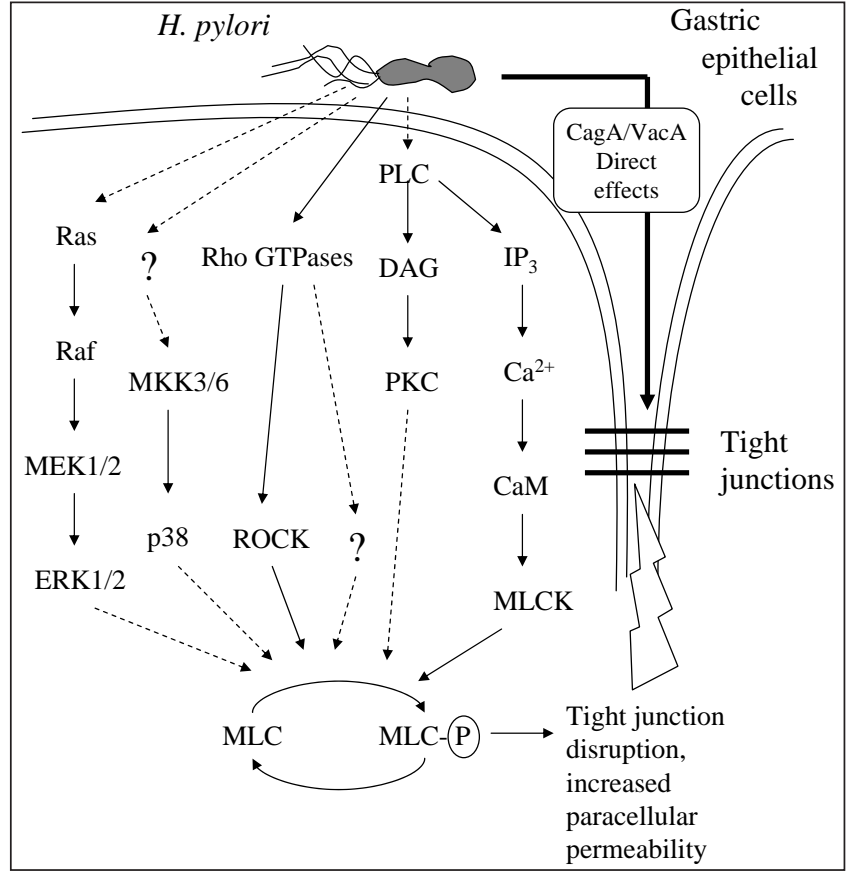

Figure 3) Illustration of the various signaling pathways through which $\mathrm{H}$ pylori may disrupt epithelial permeability. References to specific reports for each of these steps are discussed in the text. Dotted lines illustrate links that have yet to be established. CagA Cytotoxin-associated antigen; CaM Calcium-calmodulin; DAG Diacylglyerol; ERK Extracellular signal-regulated kinase; GTPase Guanosine triphosphatase; $\mathrm{IP}_{3}$ Inositol-triphosphate; MEK Mitogen-activated protein kinase/ERK kinase; MLCK Myosin light chain kinase; PLC Phospholipase C; PKC Protein kinase C; ROCK Rho-associated kinase; VacA Vacuolating cytotoxin

Similarly, the significance of cell signalling events such as Rho-kinase-mediated events to functional parameters of epithelial barrier require further investigation. Unquestionably, microbes have evolved elaborate strategies to bypass the tight junction, including mechanisms independent of MLCK. Direct binding of microbes to tight junctional elements for example may disrupt the tight junctions and increase permeability. Examples include coxsackie B virus and adenovirus, which bind to their tight junctional receptor (coxsackie virus and adenovirus receptor), which is located between other tight junctional proteins and E-cadherin $(121,122)$. Similarly, Clostridium perfringens toxin attaches to claudin-3 via its carboxyl terminus, which in turn leads to junctional disruptions via signalling events that have yet to be uncovered (123). Epithelial attachment of reovirus is also associated with tight junctional disruptions by activating nuclear factor-kappa B, which in turn causes apoptosis (124). In addition, microbial enzymes may break down tight junctional proteins to allow the passage of antigenic material. For example, peptidases from the house dust mite Dermatophagoides pteronyssinus, a potent allergen, cleaves occludin and ZO-1, which in turn allows the penetration of antigenic material (125). Intriguingly, other observations have found that these serine and cysteine proteases were able to activate PAR (126), a phenomenon recently linked to the capability of PAR-agonists to disrupt epithelial permeability via the induction of apoptosis and the activation of MLCK $(112,127)$. Clearly, much remains to be learned about the mechanisms leading to tight junctional disruptions, and their significance for the development of novel therapeutic strategies.

\section{Signalling pathways of $H$ pylori-induced loss of barrier function}

$\mathrm{H}$ pylori activates a broad range of signalling molecules, including protein kinase C (PKC), ERK and p38 (128-131). These kinases have been shown to contribute to barrier malfunction and/or MLC phosphorylation in several in vitro models $(83,132-134)$, and the fact that MAPKs may also be implicated in cancer progression (120) further underscores the possible links between these abnormalities. Figure 3 illustrates possible signalling pathways through which $\mathrm{H}$ pylori may disrupt tight junctional function via MLC. It is not clear whether $\mathrm{H}$ pylori may increase gastric permeability via signalling cascades associated with PKC, ERK or p38. In addition, while $H$ pylori is known to activate the small Rho-GTPase $(51,135)$, it is not known whether this leads to MLC phosphorylation and impaired epithelial barrier function. Findings from a recent study (136) suggest a key role for Src homology 2 domain-containing protein-tyrosine phosphatase (SHP-2) in $\mathrm{H}$ pylori CagA-mediated signalling in adenocarcinoma gastric stomach cells. The role of ERK in the epithelial abnormalities caused by this micro-organism needs to be further investigated. $\mathrm{H}$ pylori also activates the other two members of the Rho family of small GTPases, Rac and cell division control protein 42 (Cdc42) $(128,137)$, which are known to influence tight junction assembly and epithelial permeability $(90,138)$. Indeed, it has been established that Rho-A and Rac1 are directly involved in the regulation of tight junctional structure and function (139). However, no direct link has yet been established between $\mathrm{H}$ pylori-mediated activation of Rac or Cdc42 and epithelial barrier dysfunction, nor with other cytoskeletal rearrangements known to occur in response to this bacterium (140). More research is needed to determine if strain-specific signalling causing gastric barrier disruptions may explain, at least in part, the variable clinical outcomes seen in response to $H$ pylori infection.

In addition to acting as a selective barrier, tight junctions serve as a scaffold for a number of signalling molecules, and it is becoming increasingly apparent that the tight junction is an important component of the pathways that regulate cell proliferation and differentiation. JAM attached to ZO-1 is capable of recruiting PAR3 (141). In turn, PAR3 recruits and assembles a protein complex containing atypical PKC (aPKC)-PAR3-PAR6 at the tight junction $(142,143)$. PAR6 of this complex binds Cdc42, and this Rho-family GTPase can activate $\mathrm{aPKC}$, a cascade of events that are crucial for the assembly of the epithelial tight junctions (142-144). Furthermore, Cdc42 inhibits protein trafficking to the basolateral membrane and controls the development of epithelial cell polarity (144). H pylori, through the injection of CagA, production of VacA, and possibly through the expression of an outer membrane protein alters a number of cell signalling and trafficking pathways in epithelial cells $(43,44,90-92,145)$, a number of which have detrimental effects on epithelial barrier structure and function. The additional insult of tight junctional disruption may have effects on epithelial cell adhesion and polarity. 
$H$ pylori is known to have proapoptotic properties $(106,107)$. While physiological sloughing of epithelial cells via apoptosis does not alter epithelial permeability $(146,147)$, microbially or immunologically activated apoptosis does have the ability to cause a loss of barrier function (109-112). Therefore, research findings available to date offer solid support to the hypothesis that, independently of the chronic inflammatory response to the infection, at least some strains of $H$ pylori may express virulence factors that can directly alter normal epithelial cell functioning and predispose these cells to malignant transformation.

\section{CONCLUSION}

A growing body of evidence in the scientific literature supports the hypothesis that $H$ pylori may alter epithelial tight junctional components and disrupt gastric barrier function, and that these effects may be strain-dependent. While studies $(95,96)$ in human subjects have yielded controversial findings on this topic, $H$ pylori has the ability to increase the passage of food antigens across the gastric epithelium $(97,98)$. This mechanism may represent a common route towards the development of postinfectious food allergies, which have been reported in association with $H$ pylori as well as other enteric pathogens $(99,100)$. $H$ pylori is considered a class 1 carcinogen. Cell adhesion and polarity are often lost during carcinogenesis, and a role for the

\section{REFERENCES}

1. Unidentified curved bacilli on gastric epithelium in active chronic gastritis. Lancet 1983;1273-5.

2. Cover TL, Blaser MJ. Helicobacter pylori factors associated with disease. Gastroenterology 1999;117:257-61.

3. Graham DY, Yamaoka Y. H. pylori and cagA: Relationships with gastric cancer, duodenal ulcer, and reflux esophagitis and its complications. Helicobacter 1998;3:145-51.

4. Graham DY. Can therapy even be denied for Helicobacter pylori infection? Gastroenterology 1997;113:S113-7.

5. Montecucco C, Rappuoli R. Living dangerously: How Helicobacter pylori survives in the human stomach. Nat Rev Mol Cell Biol 2001;2:457-66

6. Marshall B. Helicobacter pylori: 20 years on. Clin Med 2002;2:147-52.

7. Blaser MJ, Atherton JC. Helicobacter pylori persistence: Biology and disease. J Clin Invest 2004;113:321-33.

8. Peek RM Jr, Blaser MJ. Helicobacter pylori and gastrointestinal tract adenocarcinomas. Nat Rev Cancer 2002;2:28-37.

9. Nomura AM, Lee J, Stemmermann GN, Nomura RY, Perez-Perez GI, Blaser MJ. Helicobacter pylori CagA seropositivity and gastric carcinoma risk in a Japanese American population. J Infect Dis 2002;186:1138-44.

10. Helicobacter and Cancer Collaborative Group. Gastric cancer and Helicobacter pylori: A combined analysis of 12 case control studies nested within prospective cohorts. Gut 2001;49:347-53.

11. Eslick GD, Yan P, Xia HH, Murray H, Spurrett B, Talley NJ. Foetal intrauterine growth restrictions with Helicobacter pylori infection. Aliment Pharmacol Ther 2002;16:1677-82.

12. Solnick JV, Schauer DB. Emergence of diverse Helicobacter species in the pathogenesis of gastric and enterohepatic diseases. Clin Microbiol Rev 2001;14:59-97.

13. On SL, Hynes S, Wadstrom T. Extragastric Helicobacter species. Helicobacter 2002;7(Suppl 1):63-7.

14. Chailler P, Menard D. Establishment of human gastric epithelial (HEG) cell lines exhibiting barrier function, progenitor, and prezymogenic characteristics. J Cell Physiol 2005;202:263-74.

15. Falk P, Roth KA, Boren T, Westblom TU, Gordon JI. An in vitro adherence assay reveals that Helicobacter pylori exhibits cell lineage-specific tropism in the human gastric epithelium. Proc Natl Acad Sci 1993;90:2035-9.

16. Mahdavi J, Sonden B, Hurtig M, et al. Helicobacter pylori sabA loss of specific claudins in these events has been suggested. Indeed, in pancreatic cells, claudin-4 expression inversely correlates with metastatic potential $(53,54)$, and it was recently observed that loss of claudin-4 may be implicated in the development of gastric adenocarcinoma (55). In addition, cell adhesion is sensitive to a number of host factors, including MMP. One of these, MMP-7 (matrilysin), which is secreted by epithelial cells, was recently identified as a precursor of $H$ pyloriinduced gastric adenocarcinoma (58-60). The exact involvement of disrupted claudins and MMP-7 in the production of $\mathrm{H}$ pylori-induced loss of gastric barrier function remains unclear. Nevertheless, the loss of claudin-4 (and possibly that of other tight junctional proteins), perhaps in association with increased MMP-7, could contribute to phenotypic changes induced by $\mathrm{H}$ pylori, and thereby increase the metastatic potential of gastric epithelial cells, consistent with the hypothesis that $\mathrm{H}$ pylori-induced abnormalities at epithelial tight junctions contribute at least in part to the clinical outcome of the infection.

ACKNOWLEDGEMENTS: The studies that led to some of the findings discussed in this review were sponsored by the Alberta Heritage Foundation for Medical Research, the Natural Sciences and Engineering Research Council of Canada, and the Canadian Institute of Health Research. adhesin in persistent infection and chronic inflammation. Science 2002;297:573-8.

17. Boren T, Falk P, Roth KA, Larson G, Normark S. Attachment of Helicobacter pylori to human gastric epithelium mediated by blood group antigens. Science 1993;262:1892-5.

18. Guruge JL, Falk PG, Lorenz RG, et al. Epithelial attachment alters the outcome of Helicobacter pylori infection. Proc Natl Acad Sci 1998;95:3925-30.

19. Syder AJ, Oh JD, Guruge JL, et al. The impact of parietal cells on Helicobacter pylori tropism and host pathology: An analysis using gnotobiotic normal and transgenic mice. Proc Natl Acad Sci USA 2003;100:3467-72.

20. Noach LA, Bosma NB, Jansen J, Hoek FJ, van Deventer SJ, Tytgat GN. Mucosal tumor necrosis factor-alpha, interleukin-1 beta, and interleukin-8 production in patients with Helicobacter pylori infection. Scand J Gastroenterol 1994;29:425-9.

21. Wallace JL, Cucala M, Mugridge K, Parente L. Secretagoguespecific effects of interleukin-1 on gastric acid secretion. Am J Physiol 1991;261:G559-64.

22. El-Omar EM, Carrington M, Chow WH, et al. Interleukin-1 polymorphisms associated with increased risk of gastric cancer. Nature 2000;404:398-402.

23. Ernst P. The role of inflammation in the pathogenesis of gastric cancer. Aliment Pharmacol Ther 1999;13(Suppl 1):13-8.

24. Li H, Stoicov C, Cai X, Wang TC, Houghton J. Helicobacter and gastric cancer disease mechanisms: Host response and disease susceptibility. Curr Gastroenterol Rep 2003;5:459-67.

25. Nardone G. Review article: Molecular basis of gastric carcinogenesis. Aliment Pharmacol Ther 2003;17(Suppl 2):75-81.

26. Rogers AB, Fox JG. Inflammation and cancer. I. Rodent models of infectious gastrointestinal liver and cancer. Am J Physiol Gastrointest Liver Physiol 2004;286:361-6.

27. Goto T, Harumma K, Kitadai Y, et al. Enhanced expression of inducible nitric oxide synthase and nitrotyrosine in gastric mucosa of gastric cancer patients. Clin Cancer Res $1999 ; 5: 1411-5$

28. Miyazawa M, Susuki H, Masaoka T, et al. Suppressed apoptosis in the inflamed gastric mucosa of Helicobacter pylori-colonized iNOSknockout mice. Free Radic Biol Med 2003;34:1621-30.

29. Nam KT, Oh SY, Ahn B, et al. Decreased Helicobacter pylori associated gastric carcinogenesis in mice lacking inducible nitric oxide synthase. Gut 2004;53:1250-5. 
30. Ihrig M, Whary MT, Dangler CA, Fox JG. Gastric Helicobacter infection induces a Th2 phenotype but does not elevate serum cholesterol in mice lacking inducible nitric oxide synthase. Infect Immun 2005;73:1664-70.

31. Yamasaki R, Yokota K, Okada H, et al. 2004. Immune response in Helicobacter pylori-induced low-grade gastric mucosa-associated lymphoid tissue lymphoma. J Med Microbiol 2004;53:21-9.

32. D'Elios MM, Amedei A, Del Prete G. Helicobacter pylori antigenspecific T cell responses at gastric level in chronic gastritis, peptic ulcer, gastric cancer and low-grade mucosa-associated lymphoid tissue lymphoma. Microb Infect 2003;5:723-30.

33. Hauer AC, Finn TM, MacDonald TT, Spencer J, Isaacson PG Analysis of Th1 and Th2 cytokine production in low grade B cell gastric MALT-type lymphomas stimulated in vitro with Helicobacter pylori. J Clin Pathol 150:957-9.

34. Bjorkholm B, Sjolund M, Falk PG, Berg OG, Engstrand L, Andersson DI. Mutation frequency and biological cost of antibiotic resistance in Helicobacter pylori. Proc Natl Acad Sci USA 2001;98:14607-12.

35. Xu Q, Morgan RD, Roberts RJ, Blaser MJ. Identification of type II restriction and modification systems in Helicobacter pylori reveals their substantial diversity among strains. Proc Natl Acad Sci USA 2000;97:9671-6.

36. Ilver D, Arnqvist A, Ogren J, et al. Helicobacter pylori adhesin binding fucosylated histo-blood group antigens revealed by retagging. Science 1998;279:373-7.

37. Roth KA, Kapadia SB, Martin SM, Lorenz RG. Cellular immune responses are essential for the development of Helicobacter felisassociated gastric pathology. J Immunol 1999;163:1490-7.

38. Fox JG, Beck P, Dangler CA, et al. Concurrent enteric helminth infection modulates inflammation and gastric immune responses and reduces Helicobacter-induced gastric atrophy. Nature Med 2000;6:536-42.

39. Bayerdorffer E, Neubauer A, Rudolph B, et al. Regression of primary gastric lymphoma of mucosa-associated lumphoid tissue type after cure of Helicobacter pylori infection. MALT lymphoma study group. Lancet 1995;345:1591-4.

40. Cammarota G, Montalto M, Tursi A, Vecchio FM, Fedeli G, Gasbarrini G. Helicobacter pylori reinfection and rapid relapse of lowgrade B-cell gastric lymphoma. Lancet 1995;345:192-3.

41. Horstmann M, Erttmann R, Winkler K. Relapse of MALT lymphoma associated with Helicobacter pylori after antibiotic treatment. Lancet 1994;343:1098-9.

42. Uemura N, Okamoto S, Yamamoto S, et al. Helicobacter pylori infection and the development of gastric cancer. N Engl J Med 2001;345:784-9.

43. Higashi H, Tsutsumi R, Muto S, et al. SHP-2 tyrosine phosphatase as an intracellular target of Helicobacter pylori CagA protein. Science 2002;295:683-6.

44. Segal ED, Cha J, Lo J, Falkow S, Tompkins LS. Altered states: Involvement of phosphorylated $\mathrm{Cag} \mathrm{A}$ in the induction of host cellular growth changes by Helicobacter pylori. Proc Natl Acad Sci USA 1999:96:14559-64.

45. Correa P. Helicobacter pylori and gastric cancer: State of the art. Cancer Epidemiol Biomarkers Prev 1996;5:477-81.

46. Noach LA, Rolf TM, Tytgat GN. Electron microscopic study of association between Helicobacter pylori and gastric and duodenal mucosa. J Clin Pathol 1994;47:699-704.

47. Mueller A, Merrell DS, Grimm J, Falkow S. Profiling of microdissected gastric epithelial cells reveals a cell type-specific response to Helicobacter pylori infection. Gastroenterology 2004;127:1446-62.

48. Suriano G, Mulholland D, de Wever O, et al. The intracellular E-cadherin germline mutation V832 M lacks the ability to mediate cell-cell adhesion and to suppress invasion. Oncogene 2003;22:5716-9.

49. Jawhari AU, Noda M, Farthing MJ, Pignatelli M. Abnormal expression and function of the E-cadherin-catenin complex in gastric carcinoma cell lines. Br J Cancer 1999;80:322-30.

50. Suriano G, Oliveira C, Ferreira P, et al. Identification of CDH1 germline missense mutations associated with functional inactivation of the E-cadherin protein in young gastric cancer probands. Hum Mol Genet 2003;12:575-82.

51. Conlin VS, Curtis SB, Zhao Y, et al. Helicobacter pylori infection targets adherens junction regulatory proteins and results in increased rates of migration in human gastric epithelial cells. Infect Immun 2004;72:5181-92.
52. Fedwick JP, Lapointe TK, Meddings JB, Buret AG. Helicobacter pylori activates MLCK and disrupts claudin-4/-5 and occludin to increase epithelial permeability. FASEB J 2005;19:A779,457.10.

53. Michl P, Barth C, Buchholz M, et al. Claudin-4 expression decreases invasiveness and metastatic potential of pancreatic cancer. Cancer Res 2003;63:6265-71.

54. Michl P, Buchholz M, Rolke M, et al. Claudin-4: A new target for pancreatic cancer treatment using Clostridium perfringens enterotoxin. Gastroenterology 2001;121:678-84.

55. Lee SK, Moon J, Park SW, Song SY, Chung JB, Kang JK. Loss of tight junction protein claudin- 4 correlates with histological growthpattern and differentiation in advanced gastric adenocarcinoma. Oncol Rep 2005;13:193-9.

56. Kominsky SL, Argani P, Korz D, et al. Loss of the tight junction protein claudin-7 correlates with histological grade in both ductal carcinoma in situ and invasive ductal carcinoma of the breast. Oncogene 2003;22:2021-33.

57. Swisshelm K, Macek R, Kubbies M. Role of claudins in tumorigenesis. Adv Drug Deliv Rev 2005;57:919-28.

58. Saarialho-Kere UK, Vaalamo M, Puolakkainen P, Airola K, Parks WC, Karjalainen-Lindsberg ML. Enhanced expression of matrilysin, collagenase, and stromelysin-1 in gastrointestinal ulcers. Am J Pathol 1996;148:519-26.

59. Crawford HC, Scoggins CR, Washington MK, Matrisian LM, Leach SD. Matrix metalloproteinase-7 is expressed by pancreatic cancer precursors and regulates acinar-to-ductal metaplasia in exocrine pancreas. J Clin Invest 2002;109:1437-44.

60. Crawford HC, Krishna US, Israel DA, Matrisian LM, Washington MK, Peek RM Jr. Helicobacter pylori strain-selective induction of matrix metalloproteinase-7 in vitro and within gastric mucosa. Gastroenterology 2003;125:1125-36.

61. Wong BC, Wang WP, So WH, et al. Epidermal growth factor and its receptor in chronic active gastritis and gastroduodenal ulcer before and after Helicobacter pylori eradication. Aliment Pharmacol Ther 2004;15:1459-65.

62. Keates S, Sougioultzis S, Keates AC, et al. cag+ Helicobacter pylori induces transactivation of the epidermal growth factor receptor in AGS gastric epithelial cells. J Biol Chem 2001;276:48127-34.

63. Wallasch C, Crabtree JE, Bevec D, Robinson PA, Wagner H, Ullrich A. Helicobacter pylori-stimulated EGF receptor transactivation requires metalloprotease cleavage of HB-EGF. Biochem Biophys Res Commun 2002;295:695-701.

64. Naumann M, Crabtree JE. Helicobacter pylori-induced epithelial cell signalling in gastric carcinogenesis. Trends Microbiol 2004:12:29-36

65. Gooz M, Gooz P, Smolka AJ. Epithelial and bacterial metalloproteinases and their inhibitors in $\mathrm{H}$. pylori infection of human gastric cells. Am J Physiol Gastrointest Liver Physiol 2001;281:G823-32.

66. Mori N, Sato H, Hayashibara T, et al. Helicobacter pylori induces matrix metalloproteinase-9 through activation of nuclear factor kappaB. Gastroenterology 2003;124:983-92.

67. Curtis GH, Gall DG. Macromolecular transport by rat gastric mucosa. Am J Physiol 1992;262:G1033-40.

68. Matter K, Balda MS. Signalling to and from tight junctions. Nature Rev 2003;4:225-36.

69. Schneebergr EE, Lynch RD. The tight junction: A multifunctional complex. Am J Physiol Cell Physiol 2004;286:C1213-28.

70. Cereijido M, Shoshani L, Contreras RG. Molecular physiology and pathophysiology of tight junctions. Biogenesis of tight junctions and epithelial polarity. Am J Physiol Gastrointest Liver Physiol 2000;279:G477-82.

71. Anderson JM. Molecular structure of tight junctions and their role in epithelial transport. News Physiol Sci 2001;16:126-30.

72. Tsukita S, Furuse M, Itoh M. Multifunctional strands in tight junctions. Nature Rev Mol Cell Biol 2001;2:286-93.

73. D'Atri F, Citi S. Molecular complexity of vertebrate tight junctions. Mol Membr Biol 2002;19:103-12.

74. Nusrat A, Parkos CA, Verkade P, et al. Tight junctions are membrane microdomains. J Cell Sci 2000;113:1771-81.

75. Hollande F, Shulkes A, Baldwin GS. Signaling the junctions in gut epithelium. Science STKE 2005;277:13.

76. Furuse M, Fujita K, Hiiragi T, Fujimoto K, Tsukita S. Claudin-1 and -2: Novel integral membrane proteins localizing at tight junctions with no sequence similarity to occludin. J Cell Biol $1998 ; 141: 1539-50$ 
77. Furuse M, Hirase T, Itoh M, Nagafuchi A, Yonemura S, Tsukita S. Occludin: A novel integral membrane protein localizing at tight junctions. J Cell Biol 1993;123:1777-88.

78. Liu Y, Nusrat A, Schnell FJ, et al. Human junction adhesion molecule regulates tight junction resealing in epithelia. J Cell Sci 2000;113:2363-74.

79. Berkes J, Visvanathan VK, Savkovic SD, Hecht G. Intestinal epithelial responses to enteric pathogens: Effects on the tight junction barrier, ion transport, and inflammation. Gut 2003;52:439-51.

80. Turner JR, Rill BK, Carlson SL, et al. Physiological regulation of epithelial tight junctions is associated with myosin light-chain phosphorylation. Am J Physiol 1997;273:C1378-85.

81. Madara JL. Tight junction dynamics: Is paracellular transport regulated? Cell 1988;53:497-8

82. Scott KGE, Meddings JB, Kirk DR, Lees-Miller SP, Buret AG Intestinal infection with Giardia spp. reduces epithelial barrier function in a myosin light chain kinase-dependent fashion. Gastroenterology 2002;123:1179-90.

83. Yuhan R, Koutsouris A, Savkovic SD, Hecht G. Enteropathogenic Escherichia coli-induced myosin light chain phosphorylation alters intestinal epithelial permeability. Gastroenterology 1997;113:1873-82.

84. Zolotarevsky Y, Hechet G, Koutsouris A, et al. A membranepermeant peptide that inhibits MLC kinase restores barrier function in in vitro models of intestinal disease. Gastroenterology 2002;123:163-72

85. Wang F, Graham WV, Wang Y, Witkowsky ED, Schwarz BT, Turner JR. Interferon-gamma and tumor necrosis-alpha synergize to induce intestinal epithelial barrier dysfunction by up-regulating myosin light chain kinase expression. Am J Pathol 2005;166:409-19.

86. Ma TY, Boivin MA, Ye D, Pedram A, Said HM. Mechanisms of TNF-alpha modulation of $\mathrm{CaCo}-2$ intestinal epithelial tight junction barrier: Role of myosin-light chain kinase portein expression. Am J Physiol Gastrointest Liver Physiol 2005;288:G422-30.

87. Hazell SL, Lee A, Brady L, Hennessy W. Campylobacter pyloridis and gastritis: Association with intercellular spaces and adaptation to an environment of mucus as important factors in the colonization of the gastric epithelium. J Infectious Diseases 1986;153:658-63.

88. Censini S, Stein M, Covacci A. Cellular responses induced after contact with Helicobacter pylori. Curr Opin Microbiol 2001;4:41-6.

89. Odenbreit S, Puls J, Sedlmaier B, Gerland E, Fischer W, Haas R. Translocation of Helicobacter pylori CagA into gastric epithelial cells by type IV secretion. Science 2000;287:1497-500.

90. Amieva MR, Vogelmann R, Covacci A, Tompkins LS, Nelson WJ, Falkow S. Disruption of the epithelial apical-junctional complex by Helicobacter pylori CagA. Science 2003;300:1430-4.

91. Pelicic V, Reyrat JM, Sartori L, et al. Helicobacter pylori VacA cytotoxin associated with the bacteria increases epithelial permeability independently of its vacuolating activity. Microbiology 1999;145:2043-50.

92. Papini E, Satin B, Norais N, et al. Selective increase of the permeability of polarized epithelial cell monolayers by Helicobacter pylori vacuolating toxin. J Clin Invest 1998;102:813-20.

93. Nash S, Stafford J, Madara JL. Effects of polymorphonuclear leukocyte transmigration on the barrier function of cultured intestinal epithelial monolayers. J Clin Invest 1987;80:1104-13.

94. Goodgame RW, Malaty HM, El-Zimaity HM, Graham DY. Decrease in gastric permeability to sucrose following cure of Helicobacter pylori infection. Helicobacter 1997;2:44-7.

95. Rabassa AA, Goodgame R, Sutton FM, Ou CN, Rognerud C, Graham DY. Effects of aspirin and Helicobacter pylori on the gastroduodenal mucosal permeability to sucrose. Gut 1996;39:159-63.

96. Borch K, Sjostedt C, Hannestad U, Soderholm JD, Franzen L, Mardh S. Asymptomatic Helicobacter pylori gastritis is associated with increased sucrose permeability. Dig Dis Sci 1998;43:749-53.

97. Matysiak-Budnik T, Coffin B, Lavergne-Slove A, Sabate JM, Megraud F, Heyman M. Helicobacter pylori increases the epithelial permeability to a food antigen in human gastric biopsies. Am J Gastroenterol 2004;99:225-32.

98. Matysiak-Budnik T, van Niel G, Megraud F, et al. Gastric Helicobacter infection inhibits development of oral tolerance to food antigens in mice. Infect Immun 2003;71:5219-24.

99. Corrado G, Luzzi I, Lucarelli S, et al. Positive association between Helicobacter pylori infection and food allergy in children. Scand J Gastroenterol 1998;33:1135-9.
100. Figura N, Perrone A, Gennari C, et al. Food allergy and Helicobacter pylori infection. Ital J Gastroenterol Hepatol 1999;31:186-91.

101. Finlay BB, Falkow S. Salmonella interactions with polarized human intestinal Caco-2 epithelial cells. J Infect Dis 1990;162:1096-106.

102. Fasano A, Uzzau S, Fiore C, Margaretten K. The enterotoxic effect of zonula occludens toxin on rabbit small intestine involves the paracellular pathway. Gastroenterology 1997;112:839-46.

103. Dickman KG, Hempson SJ, Anderson J, et al. Rotavirus alters paracellular permeability and energy metabolism in Caco-2 cells. Am J Physiol Gastrointest Liver Physiol 2000;279:G757-66.

104. Sakaguchi T, Kohler H, Gu X, McCormick BA, Reinecker HC. Shigella flexneri regulates tight junction-associated proteins in human intestinal epithelial cells. Cell Microbiol 2002;4:367-81.

105. Nguyen DH, Catling AD, Webb DJ, et al. Myosin light chain kinase functions downstream of Ras/ERK to promote migration of urokinase-type plasminogen activator-stimulated cells in an integrinselective manner. J Cell Biol 1999;146:149-64.

106. Jones NL, Day AS, Jennings HA, Sherman PM. Helicobacter pylori induces gastric epithelial cell apoptosis in association with increased Fas receptor expression. Infect Immun 1999;67:4237-42.

107. Jones NL, Shannon PT, Cutz E, Yeger H, Sherman PM. Increase in proliferation and apoptosis of gastric epithelial cells in the natural history of Helicobacter pylori infection. Am J Pathology 1997;151:1695-703.

108. Jones NL, Day AS, Jennings H, Shannon PT, Galindo-Mata E, Sherman PM. Enhanced disease severity in Helicobacter pyloriinfected mice deficient in Fas signaling. Infect Immun 2002;70:2591-7.

109. Chin AC, Teoh DA, Scott KG, Meddings JB, Macnaughton WK, Buret AG. Strain-dependent induction of enterocyte apoptosis by Giardia lamblia disrupts epithelial barrier function in a caspase-3dependent manner. Infect Immun 2002;70:3673-80.

110. Abreu MT, Palladino AA, Arnold ET, Kwon RS, McRoberts JA Modulation of barrier function during Fas-mediated apoptosis in human intestinal epithelial cells. Gastroenterology 2000;119:1524-36.

111. Gitter AH, Bendfeldt K, Schulzke JD, Fromm M. Leaks in the epithelial barrier caused by spontaneous and TNF-alpha-induced single-cell apoptosis. FASEB J 2000;14:1749-53.

112. Chin AC, Vergnolle N, MacNaughton WK, Wallace JL, Hollenberg MD, Buret AG. Proteinase-activated receptor 1 activation induces epithelial apoptosis and increases intestinal permeability. Proc Natl Acad Sci USA 2003;100:11104-9.

113. Singh AB, Harris RC. Epidermal growth factor receptor activation differentially regulates claudin expression and enhances transepithelial resistance in Madin-Darby canine kidney cells. J Biol Chem 2004:279:3543-52

114. Hopkins AM, Walsh SV, Verkade P, Boquet P, Nusrat A. Constitutive activation of Rho proteins by CNF-1 influences tight junction structure and epithelial barrier function. J Cell Sci 2003; $116: 725-42$

115. Amano M, Fukata Y, Kaibuchi K. Regulation and functions of Rhoassociated kinase. Exp Cell Res 2000;261:44-51.

116. Walsh SV, Hopkins AM, Chen J, Narumiya S, Parkos CA, Nusrat A. Rho kinase regulates tight junction function and is necessary for tight junction assembly in polarized intestinal epithelia. Gastroenterology 2001;121:566-79.

117. Coleman ML, Sahai EA, Yeo M, Bosch M, Dewar A, Olson MF. Membrane blebbing during apoptosis results from caspase-mediated activation of ROCK I. Nat Cell Biol 2001;3:339-45.

118. Mills JC, Stone NL, Erhardt J, Pittman RN. Apoptotic membrane blebbing is regulated by myosin light chain phosphorylation. J Cell Biol 1998;140:627-36.

119. Sebbagh M, Renvoize C, Hamelin J, Riche N, Bertoglio J, Breard J. Caspase-3-mediated cleavage of ROCK I induces MLC phosphorylation and apoptotic membrane blebbing. Nat Cell Biol 2001;3:346-52.

120. Reddy KB, Nabha SM, Atanaskova N. Role of MAP kinase in tumor progression and invasion. Cancer Metastasis Rev 2003;22:395-403

121. Bergelson JM, Cunningham JA, Droguett G, et al. Isolation of a common receptor for cocksackie $B$ viruses and adenoviruses 2 and 5 . Science 1997;275:1320-3.

122. Walters RW, Ferimuth P, Zabner J, Welsh MJ. Adenovirus fiber disrupts CAR-mediated intercellular adhesion allowing virus escape. Cell 2002;110:789-99. 
123. Fujita K, Katahira J, Horiguchi Y, Sonoda N, Furuse M, Tsukita S. Clostridium perfringens enterotoxin binds to the second extracellular loop of claudin-3, a tight junction integral membrane protein. FEBS Lett 2000;476:258-61.

124. Barton ES, Forrest JC, Connolly JL, et al. Junction adhesion molecule is a receptor for reovirus. Cell 2001;104:441-51.

125. Wan H, Winton HL, Soeller C, et al. The transmembrane protein occludin of epithelial tight junctions is a functional target for serine peptidases from fecal pellets of Dermatophagoides pteronyssinus. Clin Exp Allergy 2001;31:279-94

126. Sun G, Stacey MA, Schmidt M, Mori L, Mattoli S. Interaction of mite allergens Der $\mathrm{p} 3$ and Der $\mathrm{p} 9$ with protease-activated receptor-2 expressed by lung epithelial cells. J Immunol 2001;167:1014-21.

127. Flynn AN, Buret AG. Proteinase-activated receptor-1 and cell apoptosis. Apoptosis 2004;9:729-37.

128. Peek RM Jr. IV. Helicobacter pylori strain-specific activation of signal transduction cascades related to gastric inflammation. Am J Physiol Gastrointest Liver Physiol 2001;280:G525-30.

129. Meyer-ter-Vehn T, Covacci A, Kist M, Pahl HL. Helicobacter pylori activates mitogen-activated protein kinase cascades and induces expression of the proto-oncogenes c-fos and c-jun. J Biol Chem 2000;275:16064-72.

130. Keates S, Keates AC, Warny M, Peek RM Jr, Murray PG, Kelly CP. Differential activation of mitogen-activated protein kinases in AGS gastric epithelial cells by cag+ and cag-Helicobacter pylori. J Immunol $1999 ; 163: 5552-9$

131. Nozawa Y, Nishihara K, Akizawa Y, et al. Protein kinase C activation by Helicobacter pylori in human gastric epithelial cells limits interleukin-8 production through suppression of extracellular signal-regulated kinase. J Pharmacol Sci 2004;94:233-9.

132. Klemke RL, Cai S, Giannini AL, Gallagher PJ, de Lanerolle P, Cheresh DA. Regulation of cell motility by mitogen-activated protein kinase. J Cell Biol 1997;137:481-92.

133. Goldberg PL, MacNaughton DE, Clements RT, Minnear FL, Vincent PA. p38 MAPK activation by TGF-beta1 increases MLC phosphorylation and endothelial monolayer permeability. Am J Physiol Lung Cell Mol Physiol 2002;282:L146-54.

134. Iwabu A, Smith K, Allen FD, Lauffenburger DA, Wells A. Epidermal growth factor induces fibroblast contractility and motility via a protein kinase $\mathrm{C}$ delta-dependent pathway. J Biol Chem 2004;279:14551-60.

135. Wroblewski LE, Noble PJ, Pagliocca A, et al. Stimulation of MMP-7 (matrilysin) by Helicobacter pylori in human gastric epithelial cells: Role in epithelial cell migration. J Cell Sci 2003;116:3017-26.

136. Higashi H, Nakaya A, Tsutsumi R, et al. Helicobacter pylori CagA induces Ras-independent morphogenetic response through SHP-2 recruitment and activation. J Biol Chem 2004;279:17205-16.

137. Naumann M, Wessler S, Bartsch C, et al. Activation of activator protein 1 and stress response kinases in epithelial cells colonized by Helicobacter pylori encoding the cag pathogenicity island. J Biol Chem 1999;274:31655-62

138. Bruewer M, Hopkins AM, Hobert ME, Nusrat A, Madara JL. RhoA, Rac1, and Cdc42 exert distinct effects on epithelial barrier via selective structural and biochemical modulation of junctional proteins and F-actin. Am J Physiol Cell Physiol 2004;287:C327-35.

139. Jou T-S. Structural and functional regulation of tight junctions by RhoA and Rac1 small GTPases. J Cell Biol 1998;142:101-15.

140. Su B, Ceponis PJ, Sherman PM. Cytoskeletal rearrangements in gastric epithelial cells in response to Helicobacter pylori infection. J Med Microbiol 2003;52:861-7.
141. Itoh M, Sasaki H, Furuse M, Ozaki H, Kita T, Tsukita S. Junctional adhesion molecule (JAM) binds to PAR-3: A possible mechanism for the recruitment of PAR-3 to tight junctions. J Cell Biol 2001;154:491-7.

142. Lin D, Edwards AS, Fawcett JP, Mbamalu G, Scott JD, Pawson T. A mammalian PAR-3-PAR-6 complex implicated in Cdc42/Rac1 and aPKC signalling and cell polarity. Nat Cell Biol 2000;2:540-7.

143. Joberty G, Petersen C, Gao L, Macara IG. The cell-polarity protein Par6 links Par3 and atypical protein kinase $\mathrm{C}$ to Cdc42. Nat Cell Biol 2000;2:531-9.

144. Kroschewski R, Hall A, Mellman I. Cdc42 controls secretory and endocytic transport to the basolateral plasma membrane of MDCK cells. Nat Cell Biol 1999;1:8-13.

145. de Bernard M, Cappon A, Del Giudice G, Rappuoli R, Montecucco C. The multiple cellular activities of the VacA cytotoxin of Helicobacter pylori. Int J Med Microbiol 2004:293:589-97.

146. Madara JL. Maintenance of the macromolecular barrier at extrusion sites in intestinal epithelium: Physiological rearrangement of tight junctions. J Membr Biol 1990;116:177-84

147. Rosenblatt J, Raff MC, Cramer LP. An epithelial cell destined for apoptosis signals its neighbors to extrude it by an actin- and myosindependent mechanism. Curr Biol 2001;11:1847-57.

148. Fasano A, Fiorentini C, Donelli G, et al. Zonula occludens toxin modulates tight junctions through protein kinase C-dependent actin reorganization, in vitro. J Clin Invest 1995;96:710-20.

149. Chen ML, Pothoulakis C, LaMont JT. Protein kinase C signaling regulates ZO-1 translocation and increased paracellular flux of T84 colonocytes exposed to Clostridium difficile toxin A. J Biol Chem 2002;277:4247-54.

150. Simonovic I, Rosenberg J, Koutsouris A, Hecht G. Enteropathogenic Escherichia coli dephosphorylates and dissociates occludin from intestinal epithelial tight junctions. Cell Microbiol 2000;2:305-15.

151. McNamara BP, Koutsouris A, O'Connell CB, et al. Translocated EspF protein from enteropathogenic Escherichia coli disrupts host intestinal barrier function. J Clin Invest 2001;107:621-9.

152. Pujuguet P, Del Maestro L, Gautreau A, Louvard D, Arpin M. Ezrin regulates E-cadherin-dependent adherens junction assembly through Rac1 activation. Mol Biol Cell 2003;14:2181-91.

153. Wu S, Lim KC, Huang J, Saidi RF, Sears CL. Bacteroides fragilis enterotoxin cleaves the zonula adherens protein, E-cadherin. Proc Natl Acad Sci USA 1998;95:14979-84

154. Dillon ST, Rubin EJ, Yakubovich M, et al. Involvement of Rasrelated Rho proteins in the mechanisms of action of Clostridium difficile toxin A and toxin B. Infect Immun 1995;63:1421-6.

155. Sonoda N, Furuse M, Sasaki H, et al. Clostridium perfringens enterotoxin fragment removes specific claudins from tight junction strands: Evidence for direct involvement of claudins in tight junction barrier. J Cell Biol 1999;147:195-204.

156. Churin Y, Al-Ghoul L, Kepp O, Meyer TF, Birchmeier W, Naumann M. Helicobacter pylori CagA protein targets the c-Met receptor and enhances the motogenic response. J Cell Biol 2003;161:249-55.

157. Mimuro H, Suzuki T, Tanaka J, Asahi M, Haas R, Sasakawa C. Grb2 is a key mediator of Helicobacter pylori CagA protein activities. Mol Cell 2002;10:745-55

158. McLaughlin J, Padfield PJ, Burt JP, O'Neill CA. Ochratoxin A increases permeability through tight junctions by removal of specific claudin isoforms. Am J Physiol Cell Physiol 2004;287:C1412-7. 


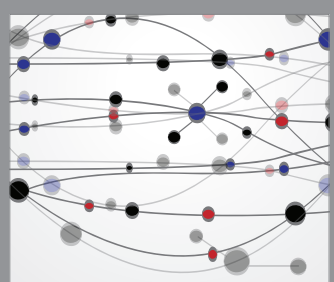

The Scientific World Journal
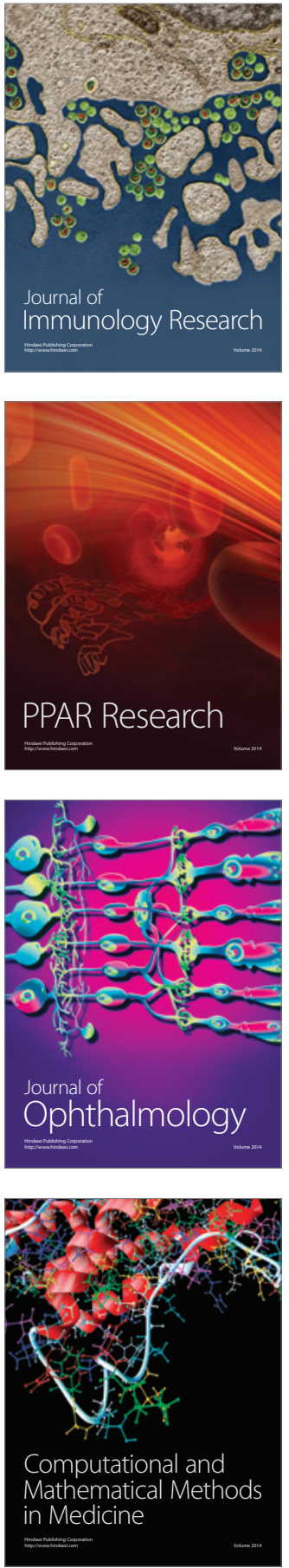

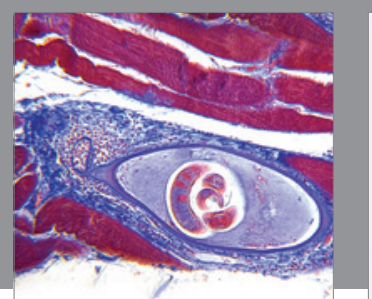

Gastroenterology Research and Practice

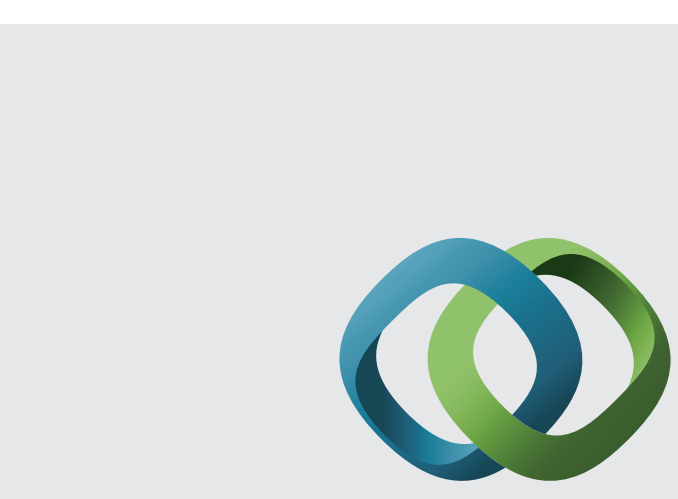

\section{Hindawi}

Submit your manuscripts at

http://www.hindawi.com
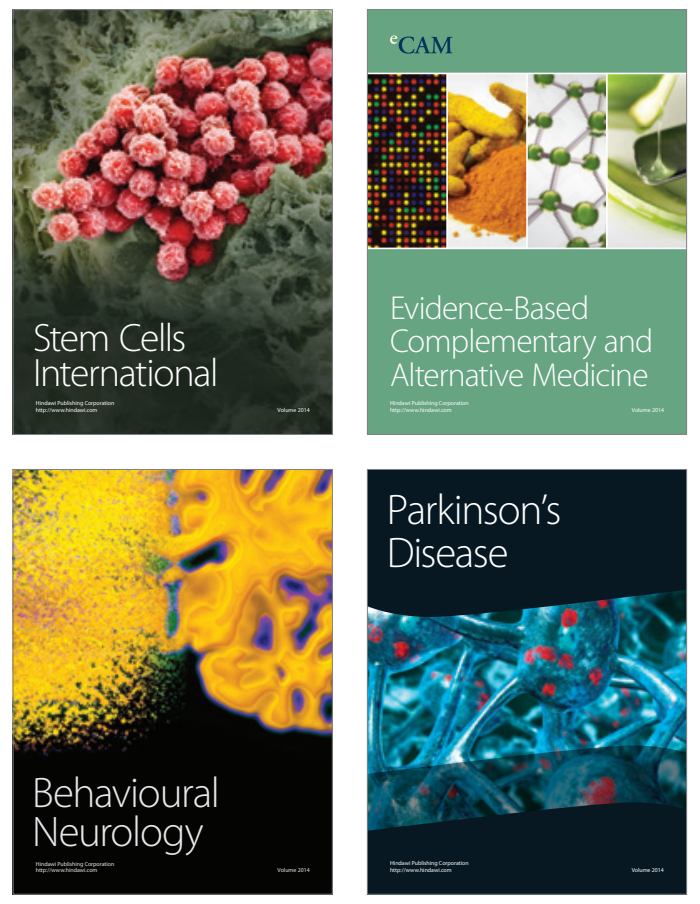
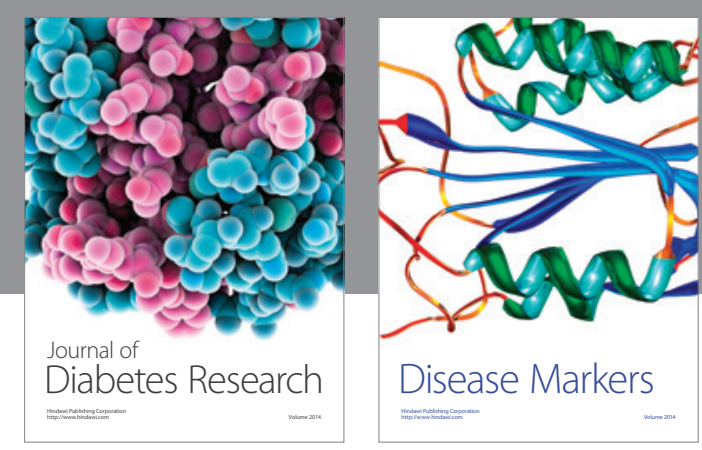

Disease Markers
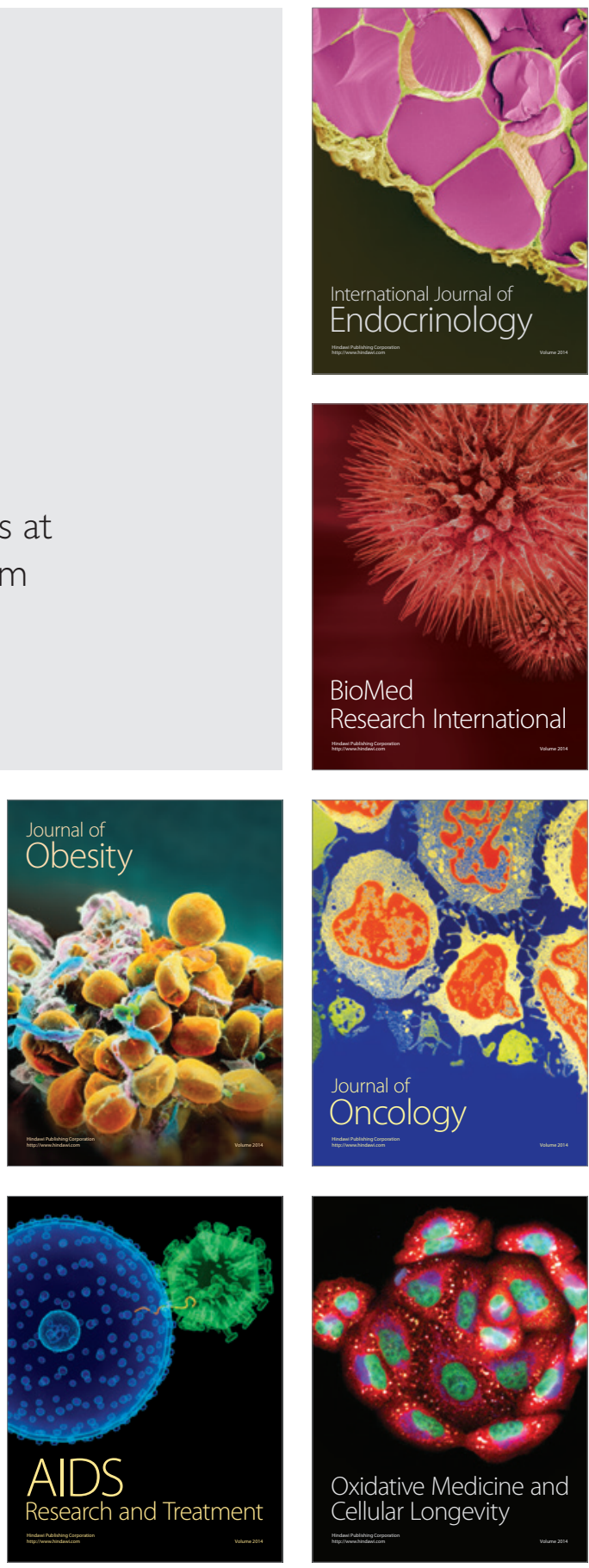